\title{
Local Knowledge in Non-formal Education: A Case Study in Historical Learning at SKB Sukoharjo
}

\author{
Ranulin Windarsari ${ }^{1}$, Djono $^{1}$, Sunardi ${ }^{1}$ \\ ${ }^{1}$ Postgraduate Program in History Education Sebelas Maret University \\ ,Ir. Sutami Street, Surakarta, Indonesia
}

\begin{abstract}
Corruption, individualism, consumptive and westernized lifestyle have become a general perspective in Indonesian society. This happens due to the globalization influence that easily affects all aspects of community life. Therefore, the government seeks to prevent and improve the lifestyle through character education program integrated into Education Unit Level Curriculum-Kurikulum Tingkat Satuan Pendidikan (KTSP). KTSP characteristic is marked by the existence of regional autonomy, primarily in educational units, that can optimize the formation of a nation's character. One of the efforts to form the nation's character is through the historical learning based on local knowledge. Historical learning with character education is not only given to formal education, but also to non-formal education. Sanggar Kegiatan Belajar (SKB) Sukoharjo is one of non-formal education units giving local knowledge to students in order to build strong character for learners and optimize the region's potential. This research aims to determine the implementation of historical learning by using local knowledge approach on non-formal education in Sanggar Belajar Belajar (SKB) Sukoharjo. This research used descriptive qualitative method by using a case study approach. Techniques of collecting data were interview, observation, and documentation. The results of this study were 1) describing the historical learning plan based on local knowledge on non-formal education, 2) describing the implementation of historical learning on non-formal education (equality) in SKB Sukoharjo with local knowledge approach in order to train and give skill to learners about local wisdom, to disseminate, understand, and go deep into the character values of local wisdom to learners, and 3) constraints on historical learning based on local knowledge on non-formal education.
\end{abstract}

Keywords: local knowledge; historical learning; non-formal education

\section{INTRODUCTION}

Syah in Chandra (2009) states that education is derived from word 'educate' which means 'to nourish' and 'to train' [1]. Both of these meanings involve teaching, guidance, and leadership associated with the mind intelligence. According to Law on National Education System (No. 20/2003: 3), Education means conscious and wellplanned effort to create a learning environment and learning process so learners so 
they are able to develop their full potential to acquire spiritual and religious strength, develop self-control, personality, intelligence, moral and noble character and skill for others. Meanwhile, Brown in Ahmadi and Uhbiyati (2004) states that education is an activity consciously, deliberately, and full responsibility carried out by adult for children to trigger continuous interaction [2]. Another definition stated by Machfoeds and Suryani (2007) that education is a number of experiences that profoundly influence the habit, attitude and knowledge associated with the health of individual, community and nation [3]. Several definitions above leads to conclusion that education is a conscious and well-planned effort to carry out the learning process through educator who aims to develop learner's intelligence, personality, and maturity, in order to reach useful learner's goal for the present and future.

Education is generally believed to hold the power to create an overall vision of life in creating human civilization. Education has relationship for various efforts in improving the quality of human life as a whole. Education effort realized in the development of the overall potential of human to be more mature and functional so that creatively can create various patterns of behaviour to fulfil life task demand. To realize and build a virtuous human character and able to compete in the future, the Indonesian government issued a curriculum policy of education tailored to the characteristics of the Indonesian nation.

Types of education in Indonesia based on Law no. 20 year 2003 article 13 paragraph 1 consists of formal education, non-formal education, and informal education. Formal education is an education implemented regularly, multilevel and comply certain requirements strictly. It usually takes place in a school or special room of building. Informal education is an education obtained consciously or unconsciously by someone from daily experience throughout life. This education can occur anywhere, such as in workplace, community, family, organization. Non-formal education is an education implemented in certain and conscious manner but it does not comply strict rules [2].

The development of education in Indonesia is managed to produce an intelligent and competitive Indonesian society through enhancement of availability, affordability, quality and relevance, equality and certainty in education acquisition. Education is a lifetime thing get along with the development of the task demand of students and complex society. However, education also leads to social inequalities and social barrier because not everyone acquires good education through formal schools to provide better provision of life to learners in the future. As a result, it emerges the government's efforts to implement education obtained by all people or called as education equality as a part of non-formal education. This is because when talking about education issues in the formation of the nation's character is through formal education in schools and less attention to other types of education such as informal education and non-formal education.

The concept of non-formal education globally is an education system that does not provide much time, detracts interaction between teacher and student, and most activities take place outside the institutions (such as reading documents at home). In addition, the characteristics of its education held by adopted formal education, however in non-formal education the process of educating is applied by a flexible curriculum and methodology based on the needs and interests of learners [4]. Nonformal education is an organized educational process that goes hand in hand with main education training system and it usually does not lead to certification [6]. 
Sheffield research (1972) about non-formal education in Africa said that non-formal education programs are expected to serve some needs, such as: as alternative for those who have no opportunity for formal education, as formal school extension for those who need extra training to put them into productive work, and as facility to improve skill for those who already work [7]. Meanwhile, non-formal education in Indonesia according to the function as education substitute, addition and/or complement can give to people that have special condition [8]. Law of Republic Indonesia Number 20 of 2003 article 26 paragraphs (6) about national education system stated that non-formal education output can be accepted as equal as the formal education output after equivalent assessment by Government or Local Government refers to national education standard. One of non-formal education programs through education equality includes Kejar Paket A program equal to Elementary school (6 years), Kejar Paket $B$ program equal to Junior High School (3 years), and Kejar Paket $C$ program equal to Senior High School (3 years). Nonformal education gives chance for students to improve the score, skill, and other competences, which is developed by formal education framework. Skill covers many competences, such as interpersonal, group, organization management and conflict, intercultural awareness, leadership, planning, organizing, coordination, teamwork, confidence, discipline, responsibility and problem solving skill.

The swift currents of globalization that are engulfing Indonesia today, have negatively impacted the growth character nations of the next generation. Corruption, individualism, consumptive and westernized lifestyle have become common opinion in Indonesian caused by globalization and modernization that requires education as key of character and personality establishment to hold character building. It becomes vulnerable when people who drop out from school or people who cannot get proper education caused by unable to face the challenge become the nation enemy. Therefore, extra efforts are needed to form the characters' nation.

Character and culture national values can obtain through history learning. History subject has strategic meaning in the form of the prestigious character and national civilization along with establishment Indonesian people who have nationalism. National personality establishment along with identity cannot be achieved without history awareness development as an inspiration and aspiration. Those characters need to be explored and inculcated through education, especially history subject, both on formal and non-formal education (equality). Historical learning in education equality is found in a non-formal education called as Kejar Paket $C$ programs which is equal to Senior High School.

Indonesian history notes that Indonesian people consist of various races, tribes, and ethnic that has local wisdom in each region. Local wisdom possession by Indonesian people has noble values which strongly root in each local cultural aspect. Local wisdom is able to lead students to love and recognize local potential to achieve local tenacity. Local autonomy can give opportunity for education to optimize the potential of local culture in national character development. Education based on local wisdom can be used as media to preserve potential of each region. Local potential is able to give chance to optimize local culture in creating character building. Therefore, historical learning based on local wisdom can be used as media to conserve character nation both in formal education and non-formal education. This is appropriate with regional autonomy is applied in Indonesia as in Law no. 32 year 2004 about Regional Government. Law no 32 year 2004 about Regional Government 
has the latest amendment with the issuance of Law no. 12 year 2008 about Regional Government with the expectation to create (1) sufficient facility and able to connect the area with the center (2) the emergence of regional creativity in the development, (3) central and regional political stability, (4) the existence of business continuity guarantee, and (5) the establishment of effective communication with stakeholders [9]. One of effort to compose national character through historical learning in nonformal education was in SKB Sukoharjo. Students in SKB Sukoharjo for Kejar Paket $C$ program consist of people that drop out from Senior High School, Junior High School graduated, worker, housewives, student of Islamic boarding school, and others with age range from 14 to 50 years old.

SKB is a non-formal education unit that organized by the local government. In the implementation of the educational equality, local governments have a special interest to develop local potentials owned through regional autonomy policy. Regional autonomy is the right, authority and obligation of the autonomous regions to regulate and manage their own governmental affairs and the interests of the local community in accordance with the laws and regulations. It can also define as the authority to self-regulate or authority to make rules in order to take care of their own household. Meanwhile, the region is a legal community with regional boundaries.

The characteristic of SKB Sukoharjo as a non-formal education is effective, which non-formal educational program can be specific with the needs and doesn't require to any strict prerequisites (teachers, methods, other facilities). The place of education can be done anywhere, such as outside the building (market, workshop, house, and other places). For doing so, the learning of history in SKB Sukoharjo can be done in the outside of the building as the spot to acquire the knowledge, one of them is at Sonorejo village which is well-known as a shadow puppet craft center. Non-formal education with local wisdom is expected to be able to build local potentials. Non-formal education graduates are expected to be able to compete as job creators by providing entrepreneurial provisions and instilling a love for local products and cultures that have value that is increasingly disappearing as the current of globalization.

The implementation of the regional government through non-formal education with the approach of regional autonomy is applied as the Law No. 12 year 2008. It is due to reason that non-formal education is more flexible and efficient to achieve the goals of regional autonomy.

The potential and the characteristic of local wisdom belong to Sukoharjo is the shadow puppet craft which is located in Sonorejo Village, Sukoharjo Subdistrict, Sukoharjo District. Shadow puppet craft in Sukoharjo become one of the learning materials in history subjects so that learners can appreciate and eager to develop the potential of that region, and learn about shadow puppet craft. Thus, there are also other local potential of Sukoharjo such as gamelan centers at Wirun, Mojolaban and herbal medicine centers at Nguter. In addition, the characteristic of learning in SKB is the provision of vocational skills. The benefits of learning in non-formal education in Indonesia in addition to getting general knowledge as in formal school education also acquire life skills that can be used as a provision of life in the future.

The results of this research are: 1) to describe lesson plan of using local knowledge-based history learning in non-formal education, 2) to describe the implementation of local knowledge-based history learning for education equality at 
SKB Sukoharjo, 3) to describe the learning obstacles of local knowledge-based history learning for non-formal education.

\section{METHODS}

This research used descriptive qualitative approach method. Qualitative research method is a research method used to examine the condition of natural objects [10]. The data analysis is inductive and the results of the research emphasize the meaning of the generalization. The strategy used in this research is case study. A case study is a more suitable strategy if the subject of a question concerns how or why, the researcher has little chance of controlling the events to be investigated, and the focus of research lies in the contemporary phenomenon in a real-life context [11].

This research is a qualitative research, the sampling technique used is sampling technique that is purposive sampling (purposive sampling), where researchers tend to choose informants who are considered to know and can be trusted entirely as a source of data and know the problems in depth [12].

The collection data used observation techniques, interviews, and documents. Observations were conducted to obtain data in the field of historical learning process in SKB Sukoharjo. Interviews were conducted with participants in this study consisting of: history tutor, head of SKB Sukoharjo, SKB learner, Sonorejo village puppet artisan. The maintaining the validity of this research used triangulation techniques, re-checking, and self-reflection. Triangulation is a technique used in qualitative research to check and build validity by analyzing data from various instruments. Triangulation used in this research is triangulation of source and triangulation method [13].

Observational data are recorded with field notes and presented in descriptive form. The research used is qualitative inductive meaning that all conclusions made up to possible theory are developed, formed from all data that have been found and collected in the field [12]. This study uses interactive model analysis techniques including three components of analysis that is data reduction, data presentation and drawing conclusions or verification. The three components of the analysis are conducted interactively and continuously.

At the beginning of the study conducted data collection which further sought the meanings, patterns, explanations, configurations, causal paths, and propositions. Data reduction is a form of analysis that sharpens, classifies, directs, discard the unnecessary, organizing the data in such a way that it can be done verification or drawing conclusions. The second plot is by presenting a set of arranged information that gives the possibility of conclusion and action taking. The presentation of the data shown can be understood what is going on and what to do. The third activity of analysis is to draw conclusions and verification [14].

\section{RESULT AND DISCUSSION}

SKB Sukoharjo is a non-formal education organization controlled by education department in Sukoharjo district. SKB Sukoharjo is one of region service unit organized by Sukoharjo education department. The purpose of $S K B$ existance is to 
assist non formal education for skill needed people. Besides, a reseach had been carried out in Sonorejo, Sukoharjo, which is a industrial centre of Traditional Puppet in Sukoharjo, Wirun village, Mojolaban district, Sukoharjo Regency.

SKB Sukoharjo is a kind of an implementation of non-formal education in Indonesia. Non formal education is an education that held out of school, either in an institution or non institution, besides the is no levels and no continuousness [15]. The curriculum in SKB Sukoharjo is Education Unit Level Curriculum (Kurikulum Tingkat Satuan Pendidikan (KTSP)). The standard of National Education article 1 verse 15 stated that the Education Unit Level Curriculum is an operational curriculum compiled and carried out by every unit of education. The compilation of KTSP was done by education unit by observed and based on the standard basic competency that developed by committee of national education standard [16]. It means that there is a autonomy in KTSP which is an implication of the policy transformation from centralization to decentralization in education.

KTSP in education equivalent with kejar paket $\mathrm{A}, \mathrm{B}$, and $\mathrm{C}$ is an operational curriculum that had been established by regency or city education department and carried out by every unit of education. Operational curriculum for education quality program consists of education purpose, structure and curriculum, educational calendar, and syllabus. The structure and content of KTSP equivalent education program consist of religion lesson group and illustrious character, citizenship education and personality development group lesson, science and technology group lesson, aesthetics lessons, and physical education, sports and health. The group of lessons carried out through learning process as stated in PP No. 19 year 2005 article 7 , that the content of KTSP consist of several lessons that covers and contains learning expenses for the students in a unit of education, besides the material and development activity has included in the curriculum [17]. The curriculum structure program after kejar paket $\mathrm{A}, \mathrm{B}$ and $\mathrm{C}$ is a pattern system of lessons and learning expenses that must be taken by the students in learning process, in the lessons and a credit unit competency.

One of the structure of group lesson is that the existence of history lesson. History is a branch of science that study about the origin and development and the citizen 's role in the past based on certain method and methodology. The equivalence education program kejar paket $\mathrm{A}, \mathrm{B}$ and $\mathrm{C}$ in formal education, the past knowledge contains sagacity or wisdom value that can be used to train intelligence, shape the attitude, character and personality of the students or learner. One of the efforts in set up the national character and personality is through history education.

The need to educate the young learner about fundamental value of humanity and sagacity is to unite the teenager in the field of culture, ethnic group and religion. These are an urge thing that needs to be done immediately to avoid the separation of the nation. According to Azra in the resarch of Niron, Budiningsih, and Pujiriyanto (2013) mentioned that multicultural education and national character must be attempted systematically, programmatically, integrated, and continuously through education institution, either formal on non-formal [18]. To prove it, it needs to combine many supported aspects to silve this national strategic problem to be more focus, comprehensive and efficient.

Specific lesson about history is studied in equivalence Kejar Paket $\mathrm{C}$ program. Kejar Paket $\mathrm{C}$ program is one of basic program that held in out of school education. Out of school education function to develop student's potential or learner citizen by 
emphasizing the knowledge mastication and functional skill and develop the attitude and professional personal. Kejar Paket $\mathrm{C}$ is one of the effort by the government to give opportunity to age school society and adult that due to many reasons could not continue the education [19].

The purpose of the study is not only transfer of knowledge but also transfer of value, not only teaching the students to be intelligence, but also having noble character. Teaching history not only to develop scientific knowledge, but also have didactic function. Didactic function of teaching history has stated implicitly and explicitly, as Sartono Kartodirdjo in Supardi (2014) stated that the aim of teaching history is the young teenager to take a lesson and power from their ancestors' experience [20]. The implementation of teaching history in SKB Sukoharjo accordance to cultivate national charcaters value to the learner that assumed insufficient because only several learner understand about leraning history.

Conformed by Tuahunse (2009) stated that if in the history learning process was organized well and professionally, the result will more satisfied indeed [21]. Therefore, the role of history teacher determines the success of learning process, especially in explaining the history material. It needs learning model with variation method that suitable to the material so students can comprehend and understand the value that contains in the historical events.

The history material in $S K B$ Sukoharjo is same with the material in formal education in general that suitable with the valid curriculum, KTSP. Besides, added with the characteristic of $S K B$ learning that give skill to the learner has suited with the learning material.

Based on mapping of credit unit competency ( $S K K)$ that used block approach in the curriculum structure will be found the lessons that done independently. The mapping of $S K K$ used the block approach in the curriculum structure is beneficial for after paket $C$ organizer that provided several days learning hours in the class.

The distinction that characterizes the learning of $S K B$ is by providing vocational skills that are adapted to regional autonomy policies to improve local potentials through flexible and flexible education. This is because the learning pattern in $S K B$ as non-formal education has 3 learning pattern that is face to face $20 \%, 30 \%$ of tutorial activities, and $50 \%$ of independent activities, so in the most portion independent activity is used as a real practice of planting the value of nation character by using local wisdom Areas to enhance and introduce the potential of the region owned.

Based on the equivalence education process, in the step of introduction of independence learning, there is a step where tutor and learner design an independent learning activity in form of learning contract that covers standard competency (SK) and basic competency (KD), kind of task, and time to finish it. The research findings are:

\section{Planning history learning based on local knowledge in SKB Sukoharjo}

The planning of history learning based local knowledge was started by composing the Syllabus and the RPP correspond to KTSP. Every educator in every education unit has to compose a good RPP in accordance with the curriculum. A good RPP has constituent component and systematic, so that it is able to represent 
any learning activities that lead to the achievement of the goals of national education. Local knowledge-based learning is done through face to face learning patterns, tutorials, and independent activities.

The implementation of education equality in Indonesia refers to applicable curriculum. Curriculum is a set of plan and arrangement about purpose, contents and lesson material as well as guidelines to hold learning activities to achieve certain education included national education purpose with a unique compatibility, condition and local potential, education units and students. Therefore, curriculum is arranged by education units to adjust education program along with local needs and potential. One of place that is used to hold education equality is SKB Sukoharjo by using applicable curriculum named KTSP that develops cultural values and national character as unity of educational activities in school.

The observation result of RPP tutor document, RPP component is suitable to KTSP that consist of unit education identity, standard competency (SK), basic competency $(\mathrm{KD})$, indicators, learning materials, learning media, learning tools and learning, materials, learning resources, learning activity measures (opening activity, the core activities, and closing activity), and evaluation of learning or assessment. Preparation of the syllabus to the study of history in $S K B$ Sukoharjo is equal to the preparation of the syllabus on formal education at school. Based on the results of interviews with Sri Mukti as the tutor of history in SKB Sukoharjo that difference between learning equipment on formal education and non-formal education (SKB Sukoharjo) is on the identity of the education unit, educational learning units include face to face, tutorials, and independent activity as well as history learning material on non-formal education is more simple than formal education. This is due to the input of the learners in the $S K B$ Sukoharjo unlike on formal education. Learners in SKB Sukoharjo consists of people who are dropouts from formal school equivalent of Senior High School, the school of the Junior High School level/MTs/ kejar paket $B$ program, people who are already working, and others. Thus, the implementation of learning is more flexible. Implementation study in SKB Sukoharjo cannot be equated with formal school. Therefore, the syllabus is adapted to learners so that the learning objective is achieved. The curriculum that used in high school and SKB are equal little difference.

The history learning equipment in SKB Sukoharjo as the public non-formal education does not show the characteristic of history learning in SKB Sukoharjo or at a formal high school. This is apparent from the documents of the RPP made by tutor only replace things like the identity of the educational unit, the term for teacher who turned into tutors, as well as the grade levels in advanced. Learning pattern consisting of $20 \%$ face-to-face activities, 30\% tutorials activities, and $50 \%$ independent activities not clearly visible on an equipment of learning. Learning equipment is made equal to the formal school with application of face-to-face activities. A special characteristic of the displayed on the learning equipment is that, there is potential for strengthening local efforts in each area of learning, including the study of history. This is due to autonomous region became the characteristic of the implementation of an appropriate KTSP learning.

The autonomous region is owned by the government of Sukoharjo caused SKB Sukoharjo entered a local knowledge in learning history. RPP and syllabus material include about local knowledge of the local area. One of region local knowledge that 
included in historical learning in SKB Sukoharjo is the craft of shadow puppets on the material learning of the Hindu-Buddhist culture acculturation and Islam in Indonesia for social class XI, Javanese musical instrument in Wirun village of Mojolaban, Wirun, as well as herbs in Nguter in have been a learning materials on folklore culture of Indonesia society before geting to know the writing in class X.

In addition to preparation of learning tools based on local wisdom, it is also prepared a learning contract. Learning contract learning strategy or learning contract is one of the methods developed by teachers to identify the various needs of students in the learning and activities that students want to do to meet those needs (Huda, 2013: 103). Learning contract is a skill, attitude, and activity, what is done by an educator with learners in the learning process. Learning contracts that are created and agreed upon by learners and educators apply only in the classroom when learning takes place, for those who violate will be punished according to class agreements. Learning contracts Self-learning is often more profound and more permanent, but teachers must be confident that there is a clear agreement on what and how things will be learned. Therefore, the learning contract should be made by involving tutors with learners who previously tutor has adapted the learning materials with Competency Standards, Basic Competencies, and Indicators to be achieved by learners.

\section{Implementation of history learning of local knowledge-based in SKB Sukoharjo}

The implementation of knowledge-based local history learning conducted in accordance with the RPP and the syllabus created by educators (tutors) at the beginning of the new school academic year. At the beginning of the tutors make a learning contract with students. The learning contract is used to clarify the same expectations, compose a learning experience, and articulate standard performance [22]. The learning contract method is a method that is developed by educators to identify various needs of learners in learning as well as the activities to be undertaken to meet the learners need. Cooperative learning method includes a learning contract that is one method that is developed by teachers to identify the various needs of students in learning and activities that will be undertaken to meet the needs of students. The steps or procedures in applying learning methods with contract learning is as follows: educators ask each student to choose a topic that the people wants to be studied and carried out independently, educators are encouraging each student to think carefully through the study plan, educators give sufficient time for consultation in drawing up the plan, educators ask for learning contracts that cover the following categories of: 1) learning objectives to be achieved by learners, 2) special knowledge and skills that must be mastered, 3) learning activities that will be utilized, 4) Evidence which will be presented by the learners to indicate that the goals that have been achieved, 5) the completion date [23].

Local-based history-based learning contracts are agreed upon by tutors and learners at the onset of face-to-face learning. Learning of local knowledge-based history is done through the pattern of independent activities by choosing a plan of study to be applied at the time of self-learning activities. Independent learning 
activities are usually done outside $S K B$ building to gain real experience. Therefore it is chosen place that can be reached by learners in order to learn independently. Tutors and learners jointly agree to determine the location that can be reached by distance and time by learners.

On independent activity is focused for learners to get knowledge through experience or direct observations. On history learning in SKB Sukoharjo through independent activity accordance to learning equipment that has been created by the tutors. Educators (tutors) direct students to do independent activities individually or in groups in accordance with certain basic competencies. Independent learning activities conducted through three stages: the early activity, preliminary activity, the core activities, and closing activities.

The preliminary activities, where in preliminary activities, educators: 1) stir up motivation and affirming the desire of learners leads to independent learning activities, 2) together with the learners independent learning designeed poured in the form of a learning contract, types of assignments, and time of completion, 3) together with the learners identify materials and other learning completeness that will be used as learning modules, resource books, and other learning media, types of assignments, and time of completion. Core activities, the implementation of core activities is the process of learning to achieve the learning objective interactive, inspiring, fun, challenging, motivating learners to participate actively, as well as providing enough room for initiative, creativity, and independence in accordance with the talents, interests and physical and psychological development of learners. In the core activity, learners: 1) Carrying out the activities in accordance to the learning objective, types of assignments, and time of completion. 2) Do the assignments in the module. 3) Periodically report on the progress of the study to obtain feedback from educators. 4) Submit the portfolio of learning outcomes as the assessment of the achievement of learning objective by educators. The closing activities, learners: 1) Perform the assessment of the results of the activities of independent study, 2) provide feedback on processes and outcomes of learning, 3) conduct follow up activities through the service of teaching improvement, enrichment materials, administering or counselling services both individually and group in accordance with the results of independent student's activities. However, most independent activities carried out outside the building $S K B$ so that learners have direct experience in the learning process. It can develop the characters' values in the learner.

Character development education is an ongoing process which never ends. The development of the culture and national character can be realized through the realm of education. One of the characters that must be having is a sense of nationalism and loves the motherland, including understanding the local culture.

Implementation of history learning based on local wisdom in SKB Sukoharjo focused on the pattern of learning through independent activities. This is because independent activities have the most portions of the learning patterns face to face or tutorial. Thus, the learning pattern with independent activities is utilized by tutors to train the learners' independence through activities outside the SKB such as visiting, observing directly, and participating directly by visiting places that have local potential areas that have local wisdom values that are tailored to the competency standard on the subject of history.

Learners do the learning activities independently in accordance with the contract of study that has been agreed with the tutor. Learners go directly to the field to gain 
knowledge and practical experience directly in the community. Learners record and ask what is encountered in the learning process. For example, IPS class XI students have learning materials about acculturation of Hindu-Buddhist and Islamic culture and indigenous culture of Indonesia. Students visited the center of wayang kulit industry in the village of Sonorejo, Sukoharjo District to gain knowledge about wayang kulit which is one of acculturation of Hindu-Buddhist and Islamic culture and indigenous culture of Indonesia which until now can be found even in small amount. Shadow puppet is an indigenous Indonesian culture that tells the story of Mahabharata and Ramayana that is adapted from India as a result of Hindu-Buddhist culture with learning adapted to Islamic teachings. Learners are also invited to know and go directly in the process of making shadow puppet in Sonorejo village.

Learners do leather puppet making activities simply by carton and cardboard media with a process tailored to the original shadow puppet making. This is because the original leather puppet making material has an expensive price. The making of shadow puppets is done through several stages, such as making patterns on wayang shapes, giving the white base colour to the puppets, puppet colouring, drying, and installing the clasps. Through the self-learning pattern of learners can learn directly and gain experience of direct skills so that can be practiced by learners. After doing observation activities and practice directly to the field learners make reports to be reported to the tutor at the time of face-to-face learning takes place.

Learners in non-formal education that are mostly not from school-age are more effective if doing self-directed learning directly. This is consistent with Kolb's opinion that adult learning will be more effective if more learning is directly involved than just passively receiving from the teacher. Kolb with his experiential learning theory lays out ideas of experience and reflection. Kolb defines four modes of learning: Concrete, experience, reflective observation, abstract conceptualization, and active experimentation.

The development of the history learning through independent activities, learners do face-to-face activities in advance to corroborate the theory on the initial meeting, and then tutors provide independent task for learners to be done independently by students. One attempt for learner self-reliance is through simple research activities with the results of research report. Students conduct research on the theme set by the educator by showing the characteristic of the local area. People have potential local areas that are expected to be in the exploration of its existence, namely craft leather puppet Sonorejo village, Sukoharjo. Based on interviews from Sri Mukti as the tutors of history, she said that independent history learning through research craft leather puppet show in the village of Sonorejo is expected that students understand, know, and gain the knowledge and skills to make shadow puppets as a potential area for local people. This is because the next generation of the nation not many people know the local potential of the local area because of eroded by currents of globalization that hit world so that local culture is considered as old and stuck culture.

Istiqomah, as learners in SKB Sukoharjo revealed that the tutor of history gives learners the task craft of leather puppet shadow in Sonorejo village. Istiqomah conducted interviews with local residents about the existence of shadow puppets in the village of Sonorejo. List of questions already compiled by Istiqomah with guidance from tutors. It is stated by Sri Mukti, the learners don't like in formal 
school. Learners in SKB Sukoharjo needs more extra guidance in learning the material though the hang out the independent independent lesson context.

Mulyati, a school employee in one of the primary school in Sukoharjo are also learners on a Kejar Paket C Program in SKB Sukoharjo revealed that she rarely followed the learning outside $S K B$ building. This is because the purpose of Mulyati studied at $S K B$ was to get a Kejar Paket $C$ educational certificate which is equivalent to a Senior High School which is the requirement of the education service that provides requisite to produce educators have perfect humility education high school level/equivalent, besides Mulyati also as a housewife. She takes care of husbands and children so that she does not have the time to do the research. To fulfil the value of learning tasks outside the building $S K B$ as research about potential local knowledge usually ask for help to the younger ones to work on, because the younger ones have much time. Mulyati said if the local wisdom potential of Sukoharjo people have already know because she lives in Sukoharjo from childhood.

Sri Mukti revealed the selection of shadow puppets as a focus of learning the historyof material culture acculturation Hindu-Buddhist and Islam in Indonesia at the social program XI, because UNESCO has established the puppet as World Master Piece of the Oral and Intangible Heritage of Humanity which is set in Paris, France on November 7, 2003, at the time Indonesia Minister of Culture and Tourism. The puppet has a high value for the puppet is one of the traditional that has been recognized by the world as a cultural heritage that will plays a major role in the formation of the national character. In addition, besides to provide knowledge about the crafts shadow puppets, it also provides knowledge about the puppet character values. According to Suwandi, as puppet craftsman, those who come to visit the village of Sonorejo were mostly students of the Art Institute of Indonesia, puppeteer, and students. This is due to the importance of the task given by the educator.

Other opinions expressed by Suyatmi, a housewife who is also learner at a Kejar Paket $\mathrm{C}$ program revealed that independent learning approach with local knowledge is very fun. Suyatmi revealed the learning process in SKB Sukoharjo is very useful for life. Suyatmi can apply and make inspiration in everyday life. Suyatmi who is a population of immigrants in Sukoharjo can know the richness of local wisdom that belongs to the people.

Based on the description above, it can be concluded that the history of local knowledge-based learning can run smoothly in accordance to the goals of the learners in SKB Sukoharjo. This is supported by research by Lestari (2015) [25] that the learners who have high learning interest will tend to be diligent, tenacious, a spirit of perseverance in learning, and happy face challenges. Learners who have a low level of interest learning, will generally be lazy learning, tend to shy away from the task. If there is a homework or other carried out mealy to meet and has waived the liability only, not concern for the task that is meaningful or not. Learners who have a low learning interest will take the role of the teacher in the learning process.

In addition besides shadow puppets, there is a local potency in Sukoharjo that need to be excavated like the gamelan in Wirun village, Mojolaban as well as industrial centres in district carrying herbs Nguter the independent learning activities history learning in grades $\mathrm{X}$ through the learning materials of folklore. It is to show that Sukoharjo have a potential local of cultural knowledge that must be kept for its existence in order to remain sustainable. Independent activities patterns are 
needed so that learners can learn independently understand the learning materials and provide hands-on experience to learners.

Historical learning based on local knowledge is requires both to give knowledge about traditional values to the learners, and provide knowledge about entrepreneurship. Graduates of Kejar Paket C program is expected to have the skills to work and or comply with the business world or industry.

The final stage is to conduct evaluation and assessment. Assessment of local knowledge-based history of the learning is done through the portfolio report of research results by learners about the knowledge of the local area. The results of assessment for learning the history of local knowledge-based region are in accordance to the criteria set by the tutor. However, not all learners collect the duties given by the tutors at the beginning of the meeting in accordance with the contract of learner. Tutor as educators must understand the learner condition, but still have to collect the duties as requirement for assessment. Assessment in SKB Sukoharjo also set the passing grade for learners that are 75. For the value of knowledge, some learners do not reach the limits of the passing grade; therefore need to work to cover the insufficiency.

\section{Constraints in learning the history of local knowledge-based in SKB Sukoharjo}

Constraints in the history of local knowledge-based learning are:

a. Constraints from educators or tutors, includes: 1) unreadiness of learners in the study, most learners who come to $S K B$ only aims to get a educational certificate equivalent to the high school level, so many students who do not attend and follow the instruction. 2) The level of understanding learners against a given task. The tasks given by the tutor is not well understood by the learners so often ambiguous between the instructions given by the tutor to learners with an understanding of learners will be the implementation of the task. 3) Assessment, learners who do not follow the learning face-to-face will have missed out on learning materials and assessment tasks as well, so the tutors are often remind learners to perform the task given.

b. Constraints of learners, although flexible learning time allows learners to perceived independent learning outside the SKB building by conducting research in the field, but not all students can afford to finish the task intime accordance to the learning contract that has been set in the beginning of learning. This is because of all learners cannot do independent activities in out place although leaners have a more flexible time, activities of learners as workers.

\section{CONCLUSSION}

Local knowledge-based on historical learning in non-formal education in $S K B$ Sukoharjo is done by planning the making of learning device which includes syllabus 
which is in accordance with KTSP. Learning history tools then applied in the learning process of history based on local knowledge is done by doing learning contract between tutors and learners. Tutor implement the learning with three patterns of learning approaches that characterize the education of equality i.e. face to face, tutorial, and independent activities.

Implementation of learning is done through initial activities, core activities, and closing activities. Learning of local knowledge-based history mostly uses an independent approach. This is to get learners' learning knowledge directly and train the independence and skills of learners. Local knowledge based learning is adapted to local potentials owned by Sukoharjo local government such as Sonorejo village puppet center, Wirun village Javanese musical intrument center, herbal medicine center in Nguter, and others with the aim of increasing local potential through education.

Obstacles in the implementation of learning history based on local knowledge mostly brought from learners. This is because the circumstances of learners are mostly workers.

\section{REFERENCES}

[1] Chandra, F. 2009. "Peran Partisipasi Kegiatan di Alam Masa anak, Pendidikan dan Jenis Kelamin sebagai Moderasi Terhadap Perilaku Ramah Lingkungan”. Disertasi S3. Program Magister Psikologi Fakultas Psikologi. Yogyakarta: Unversitas Gadjah Mada.

[2] Ahmadi, A. \& Uhbiyati, N. 2004. Ilmu Pendidikan. Jakarta: Rineka Cipta

[3] Machfoeds, I. dan Suryani, E. 2007. Pendidikan Kesehatan Bagian dari Promosi Kesehatan. Yogyakarta: Fitramaya.

[4] Dib, C.Z. 1988. Formal, Non-Formal and Informal Education: Concepts/Applicability. “Cooperative Networks in Physics Education - Conference Proceedings 173”. American Institute of Physics, New York, pp. 300-315.

[5] Ahmadi, A. 2004. Psikologi Belajar. Jakarta: Rineka Cipta.

[6] Nosodova, M. et.al. (__ ). NFE Book: The Impact of Non Formal Education on Young People and Society. Brussels, Belgium: AEGEE-Europe.

[7] Sheffield, J.R. 1972. Nonformal Education in Africa: Micro-Solutions to Macro-Problems?. African Studies Review, 15 (2), pp. 241-254. Published by: Cambridge University Press.

[8] Hermawan, I. K. D. 2012. Kinerja Pendidikan Kesetaraan sebagai Salah Satu Jenis Pendidikan Nonformal. Jurnal Pendidikan dan Kebudayaan, 18 (1), 65-84.

[9] Syaukani. 2009. Otonomi Daerah dalam Negara Kesatuan. Yogyakarta: Pustaka Pelajar.

[10] Sugiyono. 2010. Memahami Penelitian Kualitatif. Bandung: CV. Alfabeta.

[11] Yin, R. K. 2002. Studi Kasus: Desain dan Metode. Jakarta: PT Raja Grafindo Persada.

[12] Sutopo, H. B. 2006. Metodologi Penelitian Kualitatif: Dasar teori dan Terapannya dalam Penelitian. Surakarta: Universitas Sebelas Maret.

[13] Patton, M. Q. 2009. Metode Evaluasi Kualitatif. Yogyakarta: Pustaka Pelajar.

[14] Miles, M.B. \& Huberman, A. M. 2002. Analisis Data Kualitatif. Terj. Tjetjep Rohendi R. Jakarta: UI-Press.

[15] Abdulhak, I. \& Suprayogi, U. 2011. Penelitian Tindakan dalam Pendidikan Nonformal. Jakarta: PT. Raja Grafindo Persada. 
[16] Mulyasa, E. 2009. Kurikulum Tingkat Satuan Pendidikan: Sebuah Panduan Praktis. Bandung: PT. Remaja Rosdakarya.

[17] Puspawati, P. 2012. Penyusunan dan Pengembangan KTSP Program Pendidikan Kesetaraan. Diunduh di http://dikporasruweng.blogspot.co. id/2012/02/penyusunan-danpengembangan-ktsp.html diakses pada Jumat, 24 Juni 2016 pukul 13:31.

[18] Niron, M.D., Budiningsih, C.A., dan Pujiriyanto. 2013. Rujukan Integratif dalam Pelaksanaan Pendidikan Karakter di Sekolah Dasar. Jurnal Kependidikan, 43 (1), 19-31.

[19] Ciptasari, D. R. 2015. Manajemen Program Pendidikan Kesetaraan Kejar Paket C "Harapan Bangsa" di UPTD SKB Ungaran Kabupaten Semarang. Journal of Non Formal Education and Community Empowerment, 4 (2), 115-120.

[20] Supardi. 2014. Pendidikan Multikultural dalam Pembelajaran Sejarah Lokal. Jurnal Pembangunan Pendidikan: Fondasi dan Aplikasi, 2 (1), 91-99.

[21] Tuahunse, T. 2009. Hubungan Antara Pemahaman Sejarah Pergerakan Nasional Indonesia dengan Sikap Terhadap Bela Negara. Jurnal Kependidikan. XXXIX (2), 21-34.

[22] Lemieux, C.M. 2001. Learning Contract in the Classroom: Tools for Empowerment and Accountability. Social Work Education, 20 (2), 263-276.

[23] Silberman, M.L. 2009. Active Learning, 101 Strategi Pembelajaran Aktif. Yogyakarta: Pustaka Insani Madani.

[24] Marifka Wahyu Hidayat. Tempo, 22 Mei 2016. Pendidikan, Ujung Tombak Revolusi Mental. 16-22 mei 2016

[25] Lestari, I. 2015. Pengaruh Waktu Belajar dan Minat Belajar terhadap Hasil Belajar Matematika. Jurnal Formatif, 3 (2), 115-125. 